\title{
Heinrich Wilhelm Haugwitz and the Reception of Mozart's Operas in Early Nineteenth-Century Moravia
}

\author{
Martin Nedbal / mnedbal@ku.edu
}

University of Kansas, USA

\begin{abstract}
For about a decade in the early nineteenth century, the castle of Count Heinrich Wilhelm Haugwitz in Moravian Náměšt' nad Oslavou hosted a large number of musical activities centered on Mozart's operas. These activities are documented in orchestral scores, manuscript performing materials, and unusually meticulous and detailed financial records. An exploration of the Haugwitz materials associated with La finta giardiniera, Don Giovanni, and La clemenza di Tito shows that due to his historicist and literary interests the Count focused on unusual German adaptations of Mozart's Italian works as well as operas that were not common in regular repertoire of the day. The Haugwitz documents also show that the Count obtained the performing materials not only from Prague and Vienna but probably also from a previously overlooked copyist workshop in Brno.
\end{abstract}

\section{Key words}

Heinrich Wilhelm Haugwitz, Wolfgang Amadeus Mozart, Gottfried Rieger, Wenzel Mihule, Brno, Náměšt' nad Oslavou 
The music collection of Count Heinrich Wilhelm Haugwitz (1770-1842) from the castle in Namiescht an der Oslau/Náměšt nad Oslavou in Southwest Moravia is mainly known for its holding of the only surviving score of the entire original Italian version of Mozart's La finta giardiniera and a number of manuscript scores, including autographs, of Antonio Salieri, a friend of Haugwitz, to whom Salieri dedicated several compositions. ${ }^{1}$ Haugwitz and his Moravian court is also often discussed as an important center of early promotion of the works of Handel and Gluck. ${ }^{2}$ But for about a decade in the early nineteenth century, the castle also hosted a large number of activities centered on Mozart's operas in general, not just La finta giardiniera. ${ }^{3}$ What makes the Haugwitz music archive from Náměšt particularly important for Mozart reception studies is the fact that it preserves not only orchestral scores but also the performing materials, which shed new light on how Mozart's operas were approached and understood by Central European nobility in the early nineteenth century. The unusually meticulous and detailed financial records of the Haugwitz household, held in the Moravian Archive, provide a unique perspective on the chronology and operational procedures of Haugwitz's Mozart productions.

Count Haugwitz took possession of the family estate in Moravia and the Náměšt Castle in 1794, after getting his education in Vienna. During his Viennese studies, Haugwitz was acquainted with important figures of Viennese musical life, including Gottfried van Swieten, Ignaz von Mosel, Antonio Salieri, and Christoph Willibald Gluck. ${ }^{4}$ Soon after his ascension as the ruler of Náměšt́, Haugwitz initiated ambitious musical activities: in 1797 he organized a concert that featured famous Viennese cellist Anton Kraft, and in 1800 the Count's musicians performed Benda's Ariadne auf Naxos and Haydn's The

1 Many thanks to Alena Jakubcová, Jana Perutková, Michaela Ratolístková, and Jiří Sehnal for their assistance in researching Moravian archival materials for this study.

On Salieri, see HETTRICH, Jane Schattkin. Antonio Salieri's Requiem Mass: The Moravian Connection. In Mozart in Prague: Essays on Performance, Patronage, Sources, and Reception. Kathryn Libin (ed.). Prague: Czech Academy of Sciences, 2016, p. 31-43. On La finta, see BERKE, Dietrich. Die Bedeutung der Handschrift "A 17036" des Mährischen Museums in Brünn für die Edition von W. A. Mozarts Oper "La finta giardiniera" KV 196 im Rahmen der "Neuen Mozart-Ausgabe”. Mozart-Jahrbuch, 1986, p. 133-141; and JONÁŠOVÁ, Milada. Mozarts La finta giardiniera 1796 in Prag und ein unbekanntes Fragment der italienischen Version der Oper. Mozart-Jahrbuch, 2005, p. 3-54.

2 On Handel, see RACEK, Jan. Skladby Georga Friedricha Handla na zámku v Náměšti nad Oslavou. Časopis Moravského Muzea: Védy společenské, 1973, vol. 58, p. 141-162; and ANGERMÜLLER, Rudolph. Händel-Übersetzungen des Grafen Heinrich Wilhelm von Haugwitz. Händel Jahrbuch, 1992, vol. 38, p. 33-51. On Gluck, see SEHNAL, Jiří. Gluck im Repertoire des Schlosstheaters des Grafen Haugwitz in Náměšt nad Oslavou. In Kongressbericht Gluck in Wien. Gerhard Croll (ed.). New York: Bärenreiter, 1989, p. 171-177; FREEMANOVÁ, Michaela. Heinrich Wilhelm Haugwitz: 'Übersetzer der Iphigenia in Aulis'. Hudební věda 2003, vol. 40, no. 4, p. 361-370.

3 For a brief discussion of Haugwitz's approach to Cosi fan tutte and Don Giovanni, see BLAHYNKA, Miloslav. Der Zweck der Überarbeitungen von Opern- und Oratorienwerke durch Heinrich Wilhelm Haugwitz. In Haugwitzové a hudba: Sbornik přednášek z muzikologického sympózia konaného na zámku v Náměšti nad Oslavou dne 22. záři 2002 v rámci projektu "Vivat musica" u přiležitosti výroči 250 let od zakoupeni panstvi rodem Haugwitzů. Náměšt nad Oslavou: Národní památkový ústav, 2003, p. 33-38. The orchestral score for Idomeneo is also briefly discussed in BROWN, Bruce Alan, ed. Idomeneo: Kritischer Bericht, Serie II, Werggruppe 5, vol. 11 of Neue Mozart Ausgabe. New York: Bärenreiter, 2005, p. 62-63.

4 See BUŠ, Marek. Hudba na zámku v Náměšti nad Oslavou. Telč: Národní památkový ústav, 2016, p. 28. 
Creation. ${ }^{5}$ Haugwitz's musical activities grew substantially in the following decades, financed by the earnings from a textile factory that the Count founded in Náměšt in 1795. Several opera performances were common every year until Haugwitz's death in $1842 .{ }^{6}$

\section{Haugwitz's Financial Records and Mozart}

The financial records of the Count also show purchases of performing materials associated with Mozart's operas starting in 1801, when he obtained a copy of Don Giovanni. In 1802, the Count added materials from Die Zauberflöte and La clemenza di Tito to his library, in 1803 Le nozze di Figaro, in 1805 Cosi fan tutte and Die Entführung aus dem Serail, and in 1806 Idomeneo. According to the financial records, some of these additions were clearly inspired by Viennese productions of Mozart's operas, which the Count attended during his winter sojourns in the imperial capital, and to which he also sent members of his staff (for a list of Mozart-related notes in Haugwitz's financial books, see Tab. 1). For example, on December 7, 1804, the Count bought a reserved seat for the performance of Cosi fan tutte at the Vienna court theater (the Count lived in Vienna from December 1804 to March 1805). ${ }^{7}$ For that same performance, the Count also purchased cheaper tickets, which he gave to his employees, the servant and voice teacher Joseph Novotny and the servant and tenor Johann Schandera. In the following months, the financial records document several purchases of musical materials associated with Cosi fan tutte. Most importantly on March 29, 1805, the Viennese copyist Wenzel Sukowaty was paid 60 florins for a score of Cosi fan tutte, and that same day Viennese book binder Geisler was paid for binding the opera, likely the manuscript obtained from Sukowaty, into two volumes. ${ }^{8}$ These two volumes are still part of the Haugwitz music archive. ${ }^{9}$ Sometimes, the Count would also obtain operatic materials based on productions that he himself could not attend. This was the case with Idomeneo, which was produced at the Vienna court theater in May and June 1806, when the Count was at his Moravian estate. Yet, the financial records show that he purchased the score and the libretto of the opera on December 24, 1806, during his winter season in Vienna. ${ }^{10}$ The note about Idomeneo in the financial records may refer to the Idomeneo score preserved in the music archive. ${ }^{11}$

5 Moravský zemský archiv Brno [Moravian Archive in Brno] (hereafter MZA), G 142, kn. 65.

6 The chronology and frequency of some of these opera performances are discussed in SEHNAL, op. cit., 1989, p. 172-176.

7 MZA, G 142, kn. 75. On the dates of the Count's stays in Vienna, see SEHNAL, Jiř́i. Hudebníci Jindřicha Viléma Haugwitze. In Haugwitzové a hudba: Sbornik přednâšek z muzikologického sympózia konaného na zámku v Náměšti nad Oslavou dne 22. zárí 2002 v rámci projektu "Vivat musica" u př́ležitosti výroči 250 let od zakoupení panstvi rodem Haugwitzů. Náměšt nad Oslavou: Národní památkový ústav, 2003, p. 54.

8 MZA, G 142, kn. 75.

9 Moravské zemské muzeum Brno [Moravian Museum in Brno] (hereafter MZM), A 17031a-b.

10 MZA, G 142, kn. 79

11 MZM, A 17034a-c. 
Table 1: Chronological List of Selected References to Mozart in the Haugwitz Financial Records

\begin{tabular}{|c|c|c|}
\hline $\begin{array}{l}\text { Date } \\
1801-11-18\end{array}$ & $\begin{array}{l}\text { Item } \\
\text { Dem Rieger für Copiatur des Don Juan von Mozart }\end{array}$ & $\begin{array}{l}\text { Cost } \\
20 \mathrm{fl}\end{array}$ \\
\hline $1802-3-17$ & $\begin{array}{l}\text { Dem Rieger für gelieferte Zauberflöte } \\
\text { Dem Rieger für gelieferten Auszug aus Clemenza von Mozart }\end{array}$ & $\begin{array}{l}29.39 \mathrm{fl} . \\
21.52 \mathrm{fl} .\end{array}$ \\
\hline $1803-11-25$ & $\begin{array}{l}\text { Dem Bedienten Ferdinand für Notenschreiben zu Figaros Hochzeit } \\
\text { Violon Stimme } 7 \text { Bogen a } 5 x\end{array}$ & $0.35 \mathrm{fl}$. \\
\hline $1804-12-3$ & Für Partitur von Don Juan an Rieger & $20 \mathrm{fl}$. \\
\hline $1804-12-7$ & $\begin{array}{l}2 \text { gesperrte Sitz im Hoftheater/Fiaker dahin/Sesselträger nach } \\
\text { Hause [for Cosi fan tutte] }\end{array}$ & $\begin{array}{l}1.12 \mathrm{fl} . / 0.24 \\
\mathrm{fl} . / 0.30 \mathrm{fl}\end{array}$ \\
\hline $1804-12-7$ & Opern entrée für Novottny und Schandera bey Op. Cosi Fan tutte & $1 \mathrm{fl}$. \\
\hline $1804-12-27$ & $\begin{array}{l}\text { Clemenza di Tito im Clavierauszug } \\
3 \text { einzelne Arien aus der Zauberflöte }\end{array}$ & $\begin{array}{l}4.28 \mathrm{fl} . \\
0.28 \mathrm{fl}\end{array}$ \\
\hline $1804-12-31$ & $\begin{array}{l}\text { Theater entrée für Schandera und Novottny bey Clemenza di Tito } \\
\text { Für Copiatur u. Einband der } 3 \text { St. Opern Zauberflöte, Entführung } \\
\text { aus dem Serail, und Figaro }\end{array}$ & $\begin{array}{l}1 \mathrm{fl} . \\
79,07 \mathrm{fl}\end{array}$ \\
\hline $1805-2-11$ & 6 Büchl von der Zauberflöte & $2 \mathrm{fl}$. \\
\hline $1805-3-11$ & Ein gesperrter Sitz bei Don Juan & $0.56 \mathrm{fl}$. \\
\hline $1805-3-30$ & $\begin{array}{l}\text { Dem Copisten Sukowaty für Partitur der Oper Raul der Blaubart... } \\
\text { Op. Cosi fan tutte von Mozart } \\
\text { Dem Buchbinder Geisler für } 2 \text { Bände Partitur Op. Cosi fan tutte }\end{array}$ & $\begin{array}{l}40 \mathrm{fl} . \\
60 \mathrm{fl} . \\
2.36 \mathrm{fl} .\end{array}$ \\
\hline $1805-5-30$ & Dem Dussik für Copiatur Cosi fan tutte & $24.09 \mathrm{fl}$. \\
\hline $1805-6-14$ & Für Copiatur des 2ten Akts Cosi fan tutte & $19.11 \mathrm{fl}$. \\
\hline $1805-6-30$ & $\begin{array}{l}\text { Dem Ferdinand für Copiatur des } 1 \text { ten und } 2 \text { ten Akts Figaros Hochzeit } \\
\text { Für Copiatur des } 2 \text { ten und 3ten Theil Entführung aus dem Serail } \\
\text { Copiatur des } 1 \text { ten Akts die Entführung }\end{array}$ & $\begin{array}{l}7.44 \mathrm{fl} . \\
16.53 \mathrm{fl} . \\
8.55 \mathrm{fl}\end{array}$ \\
\hline $1805-7-7$ & Für Copiatur des 3ten und 4ten Akts Figaros Hochzeit & $12.48 \mathrm{fl}$. \\
\hline $1805-8-9$ & Copiatur der Opera Don Juan & $22.18 \mathrm{fl}$. \\
\hline $1805-9-14$ & Für Copiatur der Zauberflöte & $21.3 \mathrm{fl}$. \\
\hline $1805-9-30$ & $\begin{array}{l}\text { Für den deutschen Text zu Così fan tutte } \\
\text { Detto Palmira } \\
\text { Für Manuscript von Don Juan }\end{array}$ & $\begin{array}{l}4 \mathrm{fl} . \\
4 \mathrm{fl} . \\
6 \mathrm{fl}\end{array}$ \\
\hline $1806-12-24$ & Für die Oper Idomeneo samt Büchel von Gutisten [?] & $50.20 \mathrm{fl}$. \\
\hline $1807-7-5$ & Für Copiatur der Singstimmen von der Zauberflöte & $5.8 \mathrm{fl}$. \\
\hline $1807-7-31$ & Für Copiatur der Singstimmen von der Zauberflöte & $7.17 \mathrm{fl}$. \\
\hline $1807-8-28$ & Für Copiatur der Singstimmen von Don Juan et Faniska & $8.45 \mathrm{fl}$. \\
\hline $1807-12-17$ & Für 3 Opernbüchl von Don Juan, Hadrian, et Orpheus & $0.58 \mathrm{fl}$. \\
\hline $1810-1-20$ & Copiatur 3 Chorstimmen zu Titus & $024 \mathrm{fl}$. \\
\hline $1813-4-12$ & Für 2 Partituren v. Don Juan und Titus dem Strnieschtin nach Prag & $21 \mathrm{fl}$. \\
\hline $1818-12-1$ & Für erhaltene Musikalien von Prag & $22.80 \mathrm{fl}$. \\
\hline
\end{tabular}




\section{La finta giardiniera}

The Haugwitz financial records contain a hint at the origin of the famous La finta giardiniera score. As Milada Jonášová has explained, the score originated in the Prague copyist workshop of Anton Grams, likely in the last decade of the eighteenth century. ${ }^{12}$ Jonášová also noticed that the Náměšt score is missing a portion of the second act, and that this missing portion is bound into another score, preserved at the Premonstratensian Monastery in Strahov in Prague. ${ }^{13}$ Portions of the Strahov score and the Náměšt score therefore belonged together at one time, as did a manuscript Italian libretto of the opera, also preserved in Náměšt́. ${ }^{14}$ According to Jonášová, the Strahov score was put together from manuscript fragments of Mozart opera scores by Johann Nepomuk Gerlach Strniště, the music director at Strahov starting in 1807. The Náměšt financial records show musical connections between Count Haugwitz and the Strniště family in the 1810s. In 1813, Josef Strniště, an oboist in the service of Haugwitz and brother of Johann Nepomuk, was sent to Prague for unspecified scores of Don Giovanni and La clemenza di Tito. ${ }^{15}$ In 1818, furthermore, Johann Nepomuk Gerlach Strniště sent some music materials to Náměšt from Prague. ${ }^{16}$ One wonders whether in one of these shipments, or another shipment unspecified in the account books from the 1810 s, Strniště may have also sent the score of La finta giardiniera. That the score got to Náměšt only in the 1810s is consistent with the way in which the Haugwitz's music library grew, according to the financial records. In the first decade of the nineteenth century, Haugwitz focused on acquiring operas performed in Vienna at the time (besides Mozart, scores by Salieri, Cherubini, Winter, and Paer were also purchased). ${ }^{17}$ But in the second decade, he copied scores by earlier composers, such as Gluck. As an early work from the 1770s that was not part of the standard repertoire in the early nineteenth century, La finta giardiniera may have become of interest for the Count only during the 1810s, precisely when he had dealings with Strniště.

\section{Don Giovanni}

In addition to Prague and Vienna, Haugwitz also obtained performing materials for Mozart's operas from the Moravian capital Brünn/Brno. This was most likely the case with the two-volume manuscript score of Don Giovanni. The score contains a German version of the opera that is nearly identical to an adaptation that was created for Wenzel Mihule's Patriotic Theater in Prague during the $1790-1791$ season. ${ }^{18}$ Mihule's Don

12 JONÁŠOVÁ, op. cit., p. 53.

13 JONÁŠOVÁ, op. cit., p. 16.

14 On the libretto, see JONÁŠOVÁ, op. cit., p. 48-52.

15 MZA, G 142, kn. 87. See also SEHNAL, op. cit., 2003, p. 67.

16 SEHNAL, op. cit., 2003, p. 67.

17 As Sehnal points out, Haugwitz was mostly interested in serious and musically demanding works, as opposed to popular singspiels of the time (such as the works by Wenzel Müller, Ferdinand Kauer, or Gioachino Rossini). See SEHNAL, op. cit., 1989, p. 173.

18 See JAKUBCOVÁ, Alena. Die vergessenen Begegnungen: Miszellen zur zeitgenössischen Rezeption von Mozarts Bühnenwerken. In Mozart in Mannheim: Station auf dem Weg eines musikalischen Genies. Hermann Jung (ed.). Frankfurt: Peter Lang, 2006, p. 159. 
Giovanni adaptation may have arrived in Brno via Vienna, where it was produced at Schikaneder's Theater auf der Wieden in 1792, with Franz Xaver Gerl, Mozart's first Sarastro, in the title role. Gerl moved to Brno in 1793 and likely brought Mihule's Don Giovanni adaptation with him, because the opera premiered in the Moravian city just a year later, on November 3, $1794 .{ }^{19}$ In 1798, an orchestral score of Mihule's adaptation was copied in Brno and sent to the Premonstratensian Monastery in Neureisch/Nová Řiše, a South Moravian town in the vicinity of Náměšt', where it is presently still held. The monastery score is nearly identical to the Haugwitz Don Giovanni score. The monastery score bears the inscription "Chez B . . . le 6me fevrier 798 à Brün,” which suggests that it was created in Brno. The author of the two opera manuscripts may have been Gottfried Rieger (1764-1855), the music director of the Brno theater in the $1790 \mathrm{~s} .{ }^{20}$ In his position as the music director, Rieger probably supervised the first Brno production of Don Giovanni (likely in Mihule's adaptation) in 1794. Between 1805 and 1808, furthermore, Rieger became Haugwitz's court music director in Náměšt. Even before arriving in Náměšt', Rieger's name often appears in the Haugwitz financial records in connection to copies of operas and sacred vocal music. Most importantly, on November 18, 1801, Rieger was paid 20 florins for copying Don Giovanni: "dem Herr Rieger für Copiatur des Don Juan von Mozart" ("to Mr. Rieger for copying Don Juan by Mozart”). ${ }^{21}$ This suggests that Rieger ran a copyist workshop in Brno and it was he who produced both the Nová Říše score in 1798 and later also delivered the closely related Haugwitz score to Náměšt', possibly in 1801 .

There are other references to Don Giovanni materials in the Haugwitz financial records, and these suggest that the opera may have been performed in Náměšt sometime during Rieger's tenure as music director. In December 1804, the Count had Rieger purchase another score of Don Giovanni ("für Partitur von Don Juan an Rieger"). ${ }^{22}$ Since the note in the financial records refers to a score as opposed to copied music, it is possible that this 1804 purchase refers to the published Breitkopf und Härtel score which is still part of the Haugwitz music archive. ${ }^{23}$ In late summer of 1805 , the Count also paid for copying of unspecified Don Giovanni materials. ${ }^{24}$ This copying likely refers to sets of vocal and instrumental parts, which were also preserved in the Haugwitz music archive. The cost was roughly 22 florins, which is somewhat analogous to two references to copying the vocal parts ("Singstimmen") of Die Zauberflöte in the financial records for the summer

19 See Allgemeines europäisches Journal 1794, no. 12, p. 536. On Gerl in Brno, see also JAKUBCOVÁ, op. cit., p. 153-155.

20 On Rieger, see VETTERL, Karel. Bohumír Rieger a jeho doba. Časopis Matice moravské, 1929, vol. 53, p. $48-56$, p. $435-500$.

21 MZA, G 142, kn. 69. Whereas Book 69 is a chronological list, Book 67 represents the topical list of expenses, and it describes the payment without mentioning Don Giovanni specifically: "Dem Brünner Rieger für Copierung der Musikalien." The date and price match the Don Giovanni entry in the chronological book. This shows that the financial records probably do not specify all the different operas that Haugwitz had copied, many of them are simply listed as "Musikalien."

22 MZA, G 142, kn. 74.

23 MZM, A 17032a-b.

24 MZA, G 142, kn. 76 and 77. 
of 1807: the two copying tasks were priced at 12.97 florins. ${ }^{25}$ Additional vocal parts for Don Giovanni were copied (together with parts for Faniska) in the summer of $1807 .{ }^{26}$ The two references to copying materials for a single opera may be related to the fact that the Haugwitz archive contains multiple sets of incomplete vocal parts for Don Giovanni. This could also suggest that Don Giovanni was performed in at least two different productions by Haugwitz's musicians. The Haugwitz orchestral manuscript score of Don Juan, furthermore, contains penciled-in names of performers next to some of the roles. As Sehnal has shown, many of these names are listed as salaried singers in Haugwitz's financial records. ${ }^{27}$ Several of these performers are present in the records only during Rieger's time as Kapellmeister. ${ }^{28}$ Although these dates are inconsistent, they do allow the possibility that Don Juan may have been performed in Náměšt either in late summer or fall of 1807 or in late spring 1808 (the Count spend the period between December 1807 and April 1808 in Vienna). ${ }^{29}$ The performances of Mozart's operas in general likely took place in Náměšt in the first decade of the nineteenth century, because in later years the Count focused on more archaic works by Handel and Gluck, and references to Mozart's operas largely disappear from the financial records. ${ }^{30}$ Also, the limited personnel of Haugwitz's opera company reflected in the vocal parts for Mozart's operas points to the first decade of the nineteenth century; as Sehnal has shown, the number of musicians employed by the Count grew significantly in the following decades, up until the early 1840 s, and mixing of solo parts with the chorus was no longer necessary. ${ }^{31}$

The preserved vocal parts for Don Giovanni suggest that the opera was performed in a concert or semi-staged form. The parts show that individual characters were also singing with the chorus, and the soloistic parts are referred to not by the name of the character but by voice type. This is the case with the first-act part of Donna Anna, preserved in a single booklet. The part is marked "Soprano. Donna Anna," and contains not only Donna Anna's soloistic lines from No. 1 (Introduzione), No. 2 (Recitativo accompagnato ed Aria), No. 9 (Quartetto), and No. 13 (Finale), but also choral lines from No. 5 (Coro). Some of the preserved vocal parts for other Mozart operas also contain multiple characters. For example, the vocal part marked "Tenore primo" from the first act of Die Zauberflöte, contains the music for both Tamino and Monostatos, and, as Jonášová has shown, the vocal part titled "Soprano primo" from La finta giardiniera contains the music for

25 MZA, G 142, kn. 80.

26 MZA, G 142, kn. 80.

27 SEHNAL, op. cit., 2003, p. 53.

28 Donna Anna and Donna Laura were sung by "Franzl," who appears in the records between 1806 and 1809; some arias for Donna Laura are also assigned to "Marie," listed in the financial records between 1807 and 1809; Don Juan was sung by "Schandera," mentioned as a tenor in 1804; Franz by "Schlegel," mentioned between 1805 and 1840; the Commendatore and Peter by "Spindler," who appears between 1809 and 1818 ; Klärchen by "Toni," listed between 1810 and 1825; Don Gonsalvo, by "David," listed between 1808 and 1825 .

29 For the dates of Haugwitz's sojourns in Vienna, see SEHNAL, op. cit., 2003, p. 54.

30 See VETTERL, op. cit., p. 453 and 456.

31 SEHNAL, op. cit., 2003, p. 54. 
Sandrina, Arminda, Serpetta, and Ramiro. ${ }^{32}$ The vocal parts therefore must have been created only in Náměšt from materials purchased elsewhere and adjusted to the local performance forces and conditions. The local origin of the vocal and instrumental parts is also clear from the Haugwitz financial records, in which references to copying parts are often associated with specific employees of the Count.

Among the individual parts for Don Giovanni in the Haugwitz music archive, I also found a manuscript libretto, which contains both the vocal numbers and the spoken dialogue. ${ }^{33}$ The libretto is therefore the only extant copy of the spoken dialogues that accompanied Mihule's Don Giovanni adaptation, or its Viennese or Moravian variant. The manuscript libretto is possibly referred to in the financial records as well. One item, from September 30, 1805, is called "manuscript of Don Juan." ${ }^{44}$ It cost 6 florins, a lot less than what the Count usually paid for musical copies. On the same day as the Don Giovanni item, furthermore, the financial logs also reference the purchase of two other librettos, listed as German texts for Cosi fan tutte and Palmira. Each of these items cost 4 florins, a price comparable to the 6 florins paid for the unspecified Don Giovanni manuscript.

The presence of the libretto of Mihule's Prague adaptation of Don Giovanni in the Haugwitz music archive and the fact that all of the vocal parts contain that text is somewhat unusual, because by the early 1800s, Central European theaters used other, more recent German adaptations of the opera. Haugwitz had numerous German Don Giovan$n i$ adaptations to choose from. Besides Mihule's version, the Count also owned the published Breitkopf und Härtel score with the 1801 German adaptation by Friedrich Rochlitz. The Count also may have been familiar with two adaptations that had recently been performed in Viennese theaters. The first was Friedrich Lippert's reworking of the very first German Don Giovanni, created by Christian Gottlob Neefe in 1788. Lipper's adaptation was performed at the Vienna court theater between 1798 and $1803 .{ }^{35}$ The second option was also a reworking of the Neefe version, this time by Gustav Friedrich Wilhelm Grossmann, which premiered at the Theater an der Wien on October 5, 1802. Haugwitz probably attended this production during his stay in Vienna in early spring of 1805 , because the financial records feature a note about purchasing a ticket for an unspecified performance of Don Juan on March 11, $1805 .{ }^{36}$ The poster for that day from the Theater an der Wien confirms that Haugwitz must have seen Grossmann's adaptation of Don Giovanni. ${ }^{37}$

32 JONÁŠOVÁ, op. cit., p. 45.

33 MZM, A 17032LIB.

34 MZA, G 142, kn. 77.

35 On Lippert's adaptation, see NEDBAL, Martin. Mozart, Da Ponte, and Censorship: Don Giovanni and Cosi fan tutte at the Vienna Court Theater, 1798-1804. Lithes. Zeitschrift für Literatur- und Theatersoziologie [online], 2018, vol. 11, no. 15, p. 75-109. [cit. 2021-3-12]. URL: http://lithes.uni-graz.at/lithes/beitraege18_15/nedbal_mozart_daponte_censorship.pdf

36 MZA, G 142, kn. 75.

37 Theatermuseum, Vienna, Sign. 147.449 D-The. Many thanks to Claudia Mayerhofer for her assistance in locating the poster despite the Covid-19 pandemic. 
It is possible that Haugwitz chose Mihule's German adaptation to be performed at Náměšt simply because it was the version available in the orchestral manuscript in the Count's possession. But Haugwitz may have also settled on Mihule's adaptation because of his long-term historicist and literary interests. Haugwitz collected and performed historical music by Handel, Naumann, and Gluck, and after 1808, he also translated numerous eighteenth-century French and Italian opera librettos into German, starting with Gluck's Iphigénie en Aulide. ${ }^{38}$ Perhaps his endorsement of Mihule's Don Juan reflects that adaptation's closeness to the opera's original Italian version. The other widespread German adaptations, by Grossmann and Lippert, contained many more cuts, interpolations, and restructurings. At the same time, the Count or someone else from his staff also entered a few minor textual editions into the manuscript score, especially in the text of Donna Anna and Donna Laura (as Donna Elvira was called in Mihule's adaptation). For example, in the Recitative and Duet No. 2, the anonymous reviser of the Haugwitz score changed some of the textual lines to make Donna Anna appear less aggressive and more sentimental. Thus, in the Allegro starting in measure 63 (52r), Mihule's original text "Gausamer weiche, weiche," which is close to Da Ponte's "Fuggi, crudele, fuggi!," was changed, in pencil, to "Erbarme dich meiner Leiden." A similar sentimentalizing tendency can be seen at the beginning of Donna Laura's cavatina No. 3. Here, Mihule translated Da Ponte's "Ah chi mi dice mai, quel barbaro dov'è" as "Ach! wer wird mir nun sagen, wo der Verräther wohnt," and the Náměšt reviser replaced it in pencil with "Ach wer kann mir sagen, wo mein Geliebter weilt." ${ }^{9}$

\section{La clemenza di Tito}

Haugwitz's interest in unusual German adaptations of Mozart's Italian operas is also apparent from his approach to La clemenza di Tito. The Haugwitz materials for La clemenza di Tito include a Viennese edition, published by the Stamperia chymica, of the piano-vocal score by A. E. Müller. ${ }^{40}$ The Count probably bought the score in December 1804, when the purchase of the opera's piano-vocal score is listed in the financial books. ${ }^{41}$ That same month, the Count bought a ticket for the court theater performance of the opera for his two employees Schandera and Novotny. ${ }^{42}$ But the Haugwitz archive also holds a two-volume orchestral manuscript score of the opera. ${ }^{43}$ The only reference to a Tito score in the financial records is that from 1813, when Josef Strniště brought one from Prague, and it is unclear whether this might be the Haugwitz manuscript. The financial records reference Tito once more in 1802, when Rieger was paid 21.52 fl. for an "excerpt from Mozart's Clemenza” (“Auszug aus Clemenza von Mozart”). ${ }^{44}$ It is unclear

38 On Haugwitz's translation activities, see FREEMANOVÁ, op. cit., p. 361-370.

39 Textual and musical changes were typical for Haugwitz's approach to Gluck's operas as well, SEHNAL, op. cit., 1989, p. 174

40 MZM, A 17035a.

41 MZA, G 142, kn. 74.

42 MZA, G 142, kn. 75.

43 MZM, A 17035b-c.

44 MZA, G 142, kn. 68. 
what the term "excerpt" refers to, but it does raise the possibility that Rieger's copyist workshop in Brno may have been involved in providing some of the materials for Haugwitz's performances of La clemenza di Tito.

Among the Haugwitz Tito materials, there are also two manuscript librettos, and these show a connection between the Haugwitz opera activities and Hungary. Whereas the first libretto contains the sung texts that are mostly identical with those in the orchestral score, the second libretto contains spoken dialogues attributed on the front page to Franz Xaver Girzik/Jiř́k from the theater in Pest. ${ }^{45}$ The sung text translations are largely identical to a group of German variants of the opera that were popular in the Habsburg lands (they resemble the texts in Ignaz von Seyfried's 1801 adaptation of the opera for the Theater an der Wien). ${ }^{46}$ The Haugwitz manuscript scores and librettos are therefore independent of the published scores that contain the German text by Friedrich Rochlitz, first used in a 1795 piano-vocal score published in Hamburg by Böhme. Jiř́ík's spoken dialogues are unlike any other extant German adaptation, which corresponds to the fact that the Prague-born Jiř́k created his own translation for one of the earliest German productions of La clemenza di Tito, which premiered at the theater in Pest on June 11, 1798 , and in Ofen/Buda on June 18, $1798 .{ }^{47}$ It is likely that Haugwitz obtained the scores and librettos to La clemenza di Tito in the first decade of the nineteenth century, from when there are the most references to the opera in the financial records. At that time, $L a$ clemenza di Tito was popular in Vienna, with two competing productions, a German one at the Theater an der Wien and an Italian one at the court theater. Just as in the case of Don Giovanni, the Count obtained materials that were closer to the opera's original version than these contemporary Viennese adaptations, which replaced simple with accompanied recitatives, cut several arias, and interpolated others by contemporary authors. ${ }^{48}$

It is possible that just as with Mihule's Don Giovanni, Jiř́ík's spoken dialogues arrived in the Haugwitz archive via Brno. The Brno theater produced La clemenza di Tito just a few months after Pest, on October 4, 1798. The Pest production may have in fact inspired the Brno production, because it received a relatively lengthy review in the June

45 MZM, A 17035LIB.

46 Incipits of these same sung texts are also provided in Jiř́ik's libretto of spoken dialogues. It is therefore possible that Jiřík was the author of these sung texts as well. This would mean that the sung texts of the first Viennese production of La clemenza di Tito, at the Theater an der Wien in 1801, which are attributed to Joseph von Seyfried, were in fact authored by Jiř́ík in Pest in 1798.

47 Jiř́k's libretto translation received critical acclaim on the pages of the Allgemeine deutsche Theaterzeitung, a supplement of the Pressburger Zeitung published between 1798 and 1799. The Pest correspondent wrote: "Man muss Hrn. Giržik zum Ruhme nachsagen, dass wie es der Zettel meldete, er die Übersetzung nicht nach Art des Übersetzers von Profession ausarbeitete - er wahlte ungebunden an das Original Ausdrücke, die das Ohr nicht beleidigen, und zeigte wirklich das Talent eines geschickten Mannes. Man darf diese Übersetzung mehr eine Umarbeitung nennen, die wirklich den Vorzug vor so manchen Opern verdient, die nicht selten, aus dem italienischen übersetzt, eine Prosa zum durchgehen erhielt. Allgemeine deutsche Theaterzeitung (Pressburg) 1798, vol. 1, no. 7, p. 96. Cited in PRAŽÁK, Richard. Der Mozart-Kult unter den böhmischen Musikern und Theaterschaffenden an den deutschen Theatern in Ofen und Pest um 1800. Brünner Beiträge zur Germanistik und Nordistik, 2010, vol. 15, no. 1-2, p. 204.

48 See SENICI, Emanuele. La clemenza di Tito di Mozart: I primi trent'anni (1791-1821). Cremona: Brepols, 1997, p. 69-96. 
1798 issue of the Brno journal Allgemeine deutsche Theaterzeitung, a supplement of the Brünner Zeitung that appeared between 1797 and 1799. ${ }^{49}$ The titles of both the Brno and Pest productions were analogous in that they use a German title for the opera that is syntactically close to the Italian original: in Pest, the opera was called Die Grossmuth des Titus, in Brno, Die Güte des Titus. Whereas the titles of the Pest and Brno productions analogously start with Tito's virtue ("die Grossmuth" and "die Güte”), the titles of Viennese and many North German productions usually use only the emperor's name, which is sometimes followed by an adjective that refers to his virtue. For example, the very first German production of the opera, by the Joseph Seconda company in Dresden in 1796, was titled Titus der Grossmüthige, the 1797 production in Kassel and the first Vienna production, at the Theater and der Wien in 1801, were both called simply Titus. ${ }^{50}$ Haugwitz manuscript score of the opera bears the title Die Gnade des Titus, which is related to the Brno and Pest versions. It is therefore possible that Jiř́k's's German adaptation travelled from Pest to Brno, and later from Brno to Náměšt́.

\section{Haugwitz's Musical Court in Central European Context}

The Haugwitz collection of Mozart materials exceeds archival records that document early nineteenth-century reception of Mozart's opera in most large Central European cities, including Brno, Prague, and Budapest, where only small remnants of the performing materials owned by various theater directors during that period were preserved. The meticulous and unusually detailed financial records of the Haugwitz family, furthermore, allow us to get a better understanding of the chronology and provenience of the Count's musical archive. The Haugwitz music archive and the financial records that refer to it are much more extensive and well preserved than the music archive of the Lobkowicz family, another important source of information about early aristocratic reception of Mozart's operas. ${ }^{51}$ And yet, with the exception of Haugwitz's La finta giardiniera score,

49 This journal is not identical with Allgemeines europäisches Journal, another Brno periodical that appeared during the same time and contained reviews of theater performances in Central Europe. Allgemeine deutsche Theaterzeitung (Brünn) 1798, vol. 2, no. 6, p. 170. This review has been overlooked by Mozart researchers: "La clemenza di Tito, die Grossmuth des Titus, mit Musik von Mozart. Das Personal arbeitete mit vereinigten Kräften, diese Oper so gut als möglich darzustellen. Mad. Fournier als Vitellia, und Mad. Müller als Servilia wetteiferten durch gutes Spiel und Gesang sich einander den Vorzug streitig zu machen. Hr. Halla erweckte als Titus alle Zufriedenheit; Hr. Cibulka liess in der Rolle des Sextus den Künstler nich verkennen. Hr. Giržik war in der Rolle des Annius des Beifalls um so werther, da man ihn gewöhnlich im komischen Fache sieht. Obgleich die Musik das Gepräge des grossen Geistes vom ersten Range trägt, so begreift sie doch nicht alle Schönheiten, welche ein Mozart ihr zu geben fähig gewesen wäre. Sie ist im ganzen mehr für den Kenner, für den Grammatiker, der die Töne geometrisch berechnet, als für das Herz des Naturmenschen, der den ganzen Sinn vieler verborgenen, für ihn nicht genugsam herausgehobenen Schönheiten, nicht vollkommen begreifen, und empfinden kann."

50 On the Seconda and Kassel productions, see SENICI, op. cit., p. 26-28 and p. 39-47.

51 See LIBIN, Kathryn. Public Works, Private Spaces: Mozart's Operas in the Lobkowitz Theaters in Bohemia. Min-Ad: Israel Studies in Musicology, 2006, vol. 5, no. 2, p. 57-66. 
the musical material has received only minimal scholarly attention. This neglect might have to do with the fact that the Haugwitz materials contain German adaptations of Mozart's Italian operas. These adaptations have for a long time been considered inauthentic, regressive, and not as closely connected to Mozart himself as the purely Italian scores, such as those in the Lobkowicz archive.

Studies of the German reception of Mozart operas, furthermore, have until recently tended to focus predominantly on the approaches to these works in regions that remained inhabited by German speakers after WWII, as opposed to regions where German culture was prominent in the eighteenth and nineteenth centuries but from which it disappeared due to the upheavals of the early twentieth century. The Haugwitz materials connected to Don Giovanni and La clemenza di Tito point to routes of cultural transfer that stretch across many present-day political borders but were part of one large and interconnected German cultural realm in the early nineteenth century.

That most of the performance materials for Mozart's Italian operas in the Haugwitz archive pertain to German-language adaptations was one of the reasons why Czech scholars were not interested in them following the expulsion of the German minority from the Bohemian lands after WWII. During the second half of the twentieth century, furthermore, the legacy of the Haugwitz family became taboo in Moravia. During the Nazi occupation, the descendants of Count Haugwitz were forced to accept German nationality, and thus after the war, their possessions were confiscated by the Czechoslovak state and the family was forced to leave the country. ${ }^{52}$ In the following four decades of communism, memories of "decadent" aristocratic families as promoters of culture and industry in the Bohemian lands were frowned upon, as was the fact that prior to 1918, most Moravian aristocrats had an allegiance to Vienna as opposed to Prague. Thus, after WWII, the Haugwitz music archive was transferred to the Moravian Museum in Brno and was disconnected from its original context. Some researchers have in fact referred to the Haugwitz scores as Brno manuscripts. ${ }^{53}$ It was only in the last two decades, that the legacy of the Haugwitz family came to be reevaluated by Czech politicians and historians, and this reevaluation also allowed a better understanding of how the Haugwitz music archive reflects its original historical context.

But the musical and operatic patronage of the Haugwitz family also does not fit general concepts about cultural developments in the early nineteenth century. Aristocratic patronage of the arts is usually associated with the ancien régime, not so much with the nineteenth century, when historians usually focus on public institutions dominated by middle-class values. ${ }^{54}$ To some extent, Haugwitz and his musical activities represent

52 See MÍŠKKOVÁ, Alena. Hrabě Jindřich Haugwitz, poslední z rodu Haugwitzů v Náměšti. In Panství Náměšt v proměnách času: Obraz v zrcadle evropských dějin. Johanna Haugwitz-El Kalak (ed.). Telč: Národní památkový ústav, 2013, p. 154-163.

53 Ian Woodfield, for example, refers to the Haugwiz Don Giovanni score as "a score in Brno." WOODFIELD, Ian. The Vienna Don Giovanni. Rochester: Boydell Press, 2010, p. 128.

54 On the lack of research into aristocratic patronage of opera in the first half of the nineteenth century and the lack of scholarly interest in it, see PERNERSTORFER, Matthias J. Ferdinand Raimund in Telč: Zu Schlosstheater und Theaterbibliothek der Grafen Podstatzky-Lichtenstein. Nestroyana. Blätter der Internationalen Nestroy-Gesellschaft, 2012, vol. 32, no. 1-2, p. 33-46. 
a remnant of the eighteenth-century world, where noble magnates spent large sums on musical productions as part of their conspicuous consumption - Rudolf Pečman aptly referred to Count Haugwitz as a type of "an enlightened aristocrat with late Baroque features." 55 Just as the Esterházy patrons of Joseph Haydn or Johann Adam Questenberg in his Moravian estate in Jarmeritz/Jaroměřice, Haugwitz kept his own musical ensemble and cultivated relations with composers, some of whom celebrated him in their compositions (this was the case with Salieri and Rieger). ${ }^{56}$ At the same time, Haugwitz was interested in preserving and reviving music of the past to a much larger extent than his Central European predecessors. One difficulty in comparing Haugwitz's operatic productions to contemporaneous public theater activities in Central European cities is that there is no clear information about the audience that attended the Náměšt performances. ${ }^{57}$ It is therefore unclear whether the productions of substantial operatic works, particularly those from the past, that were no longer a part of the repertoire in mainstream public opera houses, represented a private whim of an music-loving nobleman, or whether they in some ways were also perceived as educational and cultivating the tastes of the guests who frequented these performances and the public in general. The fact that Haugwitz eventually did publish some of his translations of opera librettos (in some cases in multiple editions), suggests that some portion of his operatic endeavors were publicly oriented and aimed at constructing a canon of significant "masterworks" meant not only for private delectation but also for future generations of a wider audience.

In some ways, Count Haugwitz's operatic activities at his private estate are similar to those of Franz Joseph Maximilian von Lobkowicz, except the Lobkowicz operatic endeavor came to an end after less than two decades, in 1813, due to the Prince's financial troubles (Haugwitz, by contrast, continued to expand his musical activities until his death in 1842). As Kathryn Libin and others have pointed out, moreover, Lobkowicz's operatic productions often relied on professional musicians from Prague and Vienna, whereas Haugwitz mostly employed local musicians. ${ }^{58}$ Aristocratic patronage of opera was quite common in the luxurious rural abodes of other Central-European contemporaries of Haugwitz. Between 1798 and 1806, a public opera company operated at the castle of the Teutonic Knights in Freudenthal/Bruntál in the Austrian Silesia. ${ }^{59}$ Not far from Náměšt, furthermore, operatic productions were common at the South Moravian

55 PEČMAN, Rudolf. Heinrich Haugwitz und Georg Friedrich Händel. In Haugwitzové a hudba: Sborník přednášek z muzikologického sympózia konaného na zámku v Náměšti nad Oslavou dne 22. zář́ 2002 v rámci projektu "Vivat musica" u přiležitosti výroči 250 let od zakoupeni panstvi rodem Haugwitzů. Náměšt nad Oslavou: Národní památkový ústav, 2003, p. 13.

56 On Questenberg, see PERUTKOVÁ, Jana. Der glorreiche Nahmen Adami: Johann Adam Questenberg (16781752) als Förderer der italienischen Oper in Mähren. Vienna: Hollitzer, 2015. As for the music written in Náměšt́, Rieger wrote several celebratory cantatas for the Count, as well as several singspiels, and Salieri dedicated a gratulatory cantata, a requiem, and two collections of humorous vocal canons to Haugwitz.

57 SEHNAL, op. cit., 1989, p. 172.

58 See LIBIN, op. cit., p. 60-64.

59 See HANIČÁKOVÁ, Markéta. Recepce Dittersovy operní tvorby v zámeckém divadle řádu německých rytíŕ̊ v Bruntále. Musicologica Olomucensia, 2019, vol. 30, p. 57-69. 
estate of the Podstatzky-Lichtenstein family in Teltsch/Telč ${ }^{60}$ Operatic and large-scale musical productions were also organized at many estates of Bohemian nobility, by the members of the Clary-Aldringen family in Teplitz/Teplice, by the Waldstein family in Münchengrätz/Mnichovo Hradiště, by the Clam-Gallas family in Prague and Friedland/ Frýdlant, and elsewhere in Central Europe, most importantly by the Fürstenbergs in Donaueschingen. ${ }^{61}$ The main difference between Haugwitz's patronage of opera and that by his contemporaries was that many of the other families simply hosted professional opera troupes as opposed to keeping their own Hauskapellen. More comparative research into the repertoire of nineteenth-century operatic endeavors of Central European aristocrats is needed before a true understanding of the exceptionality of Haugwitz's focus on historicist repertoire can be fully understood. At the same time, it is safe to say that in their preservation and promotion of a canonic repertoire, Haugwitz and other Central European aristocrats paralleled and sometimes even paved the way for many later public, state, and national institutions of musical culture.

\section{Bibliography}

BERKE, Dietrich. Die Bedeutung der Handschrift “A 17036” des Mährischen Museums in Brünn für die Edition von W. A. Mozarts Oper "La finta giardiniera” KV 196 im Rahmen der "Neuen Mozart-Ausgabe”. Mozart-Jahrbuch, 1986, p. 133-141.

BLAHYNKA, Miloslav. Der Zweck der Überarbeitungen von Opern- und Oratorienwerke durch Heinrich Wilhelm Haugwitz. In Haugwitzové a hudba: Sbornik prednášek z muzikologického sympózia konaného na zámku v Náměšti nad Oslavou dne 22. zár̆ 2002 v rámci projektu "Vivat musica" u príležitosti výroč 250 let od zakoupeni panstvi rodem Haugwitzů. Náměšt nad Oslavou: Národní památkový ústav, 2003, p. 33-38.

BUŠ, Marek. Hudba na zámku v Náměšti nad Oslavou. Telč: Národní památkový ústav, 2016.

FREEMANOVÁ, Michaela. Heinrich Wilhelm Haugwitz: 'Übersetzer der Iphigenia in Aulis'. Hudebni věda, 2003, vol. 40, no. 4, p. 361-370.

HANIČÁKOVÁ, Markéta. Recepce Dittersovy operní tvorby v zámeckém divadle řádu německých rytî́ů v Bruntále. Musicologica Olomucensia, 2019, vol. 30, p. 57-69.

HETTRICH, Jane Schattkin. Antonio Salieri's Requiem Mass: The Moravian Connection. In Mozart in Prague: Essays on Performance, Patronage, Sources, and Reception. Kathryn Libin (ed.). Prague: Czech Academy of Sciences, 2016, p. 31-43.

JAKUBCOVÁ, Alena. Die vergessenen Begegnungen: Miszellen zur zeitgenössischen Rezeption

60 See PERNERSTORFER, op. cit., p. 33-46.

61 On Clary-Aldringen, see MICHLOVÁ, Jana. Zámecké divadlo v Teplicích: Divadelní cedule ve sbírce knihovny muzea. Teplice: Regionální muzeum v Teplicích, 2014; on the Waldstein theater in Mnichovo Hradiště, see MOHLER, Frank and Pavla Pešková. The Castle Theater in Mnichovo Hradistě. Praha: Národní památkový ústav, 2004; on Clam-Gallas, see MAŠEK, Petr, and Martin Vaňáč. Christian Phillip Graf Clam-Gallas. In Theater in Böhmen, Mähren und Schlesien: Von den Anfängen bis zum Ausgang des 18. Jahrhunderts. Alena Jakubocová and Matthias J. Pernerstofer (eds.). Vienna: Österreischische Akademie der Wissenschaften, 2013, p. 119-121; on Donaueschingen, see STRAUSS-NÉMETH, László. Johann Wenzel Kalliwoda und die Musik am Hof von Donaueschingen. New York: Olms, 2005. 
von Mozarts Bühnenwerken. In Mozart in Mannheim: Station auf dem Weg eines musikalischen Genies. Hermann Jung (ed.). Frankfurt: Peter Lang, 2006, p. 153-162.

JONÁŠOVÁ, Milada. Mozarts La finta giardiniera 1796 in Prag und ein unbekanntes Fragment der italienischen Version der Oper. Mozart-Jahrbuch, 2005, p. 3-54.

LIBIN, Kathryn. Public Works, Private Spaces: Mozart's Operas in the Lobkowitz Theaters in Bohemia. Min-Ad: Israel Studies in Musicology, 2006, vol. 5, no. 2, p. 57-66.

MAŠEK, Petr, and Martin Vaňáč. Christian Phillip Graf Clam-Gallas. In Theater in Böhmen, Mähren und Schlesien: Von den Anfängen bis zum Ausgang des 18. Jahrhunderts. Alena Jakubocová and Matthias J. Pernerstofer (eds.). Vienna: Österreischische Akademie der Wissenschaften, 2013, p. 119-121.

MICHLOVÁ, Jana. Zámecké divadlo v Teplicích: Divadelni cedule ve sbírce knihovny muzea. Teplice: Regionální muzeum v Teplicích, 2014.

MÍŠKOVÁ, Alena. Hrabě Jindřich Haugwitz, poslední z rodu Haugwitzů v Náměšti. In Panstvi Náměš̀ v proměnách času: Obraz v zrcadle evropských dějin. Johanna Haugwitz-El Kalak (ed.). Telč: Národní památkový ústav, 2013, p. 154-163.

MOHLER, Frank and Pavla Pešková. The Castle Theater in Mnichovo Hradistě. Praha: Národní památkový ústav, 2004.

NEDBAL, Martin. Mozart, Da Ponte, and Censorship: Don Giovanni and Cosi fan tutte at the Vienna Court Theater, 1798-1804. Lithes. Zeitschrift für Literatur- und Theatersoziologie, 2018, vol. 11, no. 15, p. 75-109, http://lithes.uni-graz.at/lithes/beitraege18_15/nedbal_mozart_daponte_censorship. pdf.

PEČMAN, Rudolf. Heinrich Haugwitz und Georg Friedrich Händel. In Haugwitzové a hudba, p. 13-20.

PERNERSTORFER, Matthias J. Ferdinand Raimund in Telč: Zu Schlosstheater und Theaterbibliothek der Grafen Podstatzky-Lichtenstein. Nestroyana. Blätter der Internationalen Nestroy-Gesellschaft, 2012, vol. 32, no. 1-2, p. 33-46.

PERUTKOVÁ, Jana. Der glorreiche Nahmen Adami: Johann Adam Questenberg (1678-1752) als Förderer der italienischen Oper in Mähren. Vienna: Hollitzer, 2015.

PRAŽÁK, Richard. Der Mozart-Kult unter den böhmischen Musikern und Theaterschaffenden an den deutschen Theatern in Ofen und Pest um 1800. Brünner Beiträge zur Germanistik und Nordistik, 2010, vol. 15, no. 1-2, p. 197-209.

RACEK, Jan. Skladby Georga Friedricha Handla na zámku v Náměšti nad Oslavou. Časopis Morauského Muzea: Vědy společenské, 1973, vol. 58, p. 141-162.

SEHNAL, Jiří. Gluck im Repertoire des Schlosstheaters des Grafen Haugwitz in Náměšt nad Oslavou. In Kongressbericht Gluck in Wien. Gerhard Croll (ed.). New York: Bärenreiter, 1989, p. $171-177$.

SEHNAL, Jiří. Hudebníci Jindřicha Viléma Haugwitze. In Haugwitzové a hudba, p. 53-69.

SENICI, Emanuele. La clemenza di Tito di Mozart: I primi trent'anni (1791-1821). Cremona: Brepols, 1997.

STRAUSS-NÉMETH, László. Johann Wenzel Kalliwoda und die Musik am Hof von Donaueschingen. New York: Olms, 2005.

VETTERL, Karel. Bohumír Rieger a jeho doba. Časopis Matice moravské, 1929, vol. 53, p. 48-56, p. $435-500$.

WOODFIELD, Ian. The Vienna Don Giovanni. Rochester: Boydell Press, 2010.

This work can be used in accordance with the Creative Commons BY-SA 4.0 International license terms and conditions (https://creativecommons.org/licenses/by-sa/4.0/legalcode). This does not apply to works or elements (such as image or photographs) that are used in the work under a contractual license or exception or limitation to relevant rights. 
